\title{
Cinnamomum burmannii (Nees \& T. Nees) Blume and Eleutherine palmifolia (L.) Merr. extract combination ameliorate lipid profile and heart oxidative stress in hyperlipidemic mice
}

\author{
Retno Susilowati1 ${ }^{(\mathbb{D})}$ and Abdul Malik Setiawan² (iD
}

1. Department of Biology, Faculty of Science and Technology, State Islamic University of Maulana Malik Ibrahim Malang, Malang 65144, East Java, Indonesia; 2. Department of Microbiology, Faculty of Medicine and Health Sciences, State Islamic University of Maulana Malik Ibrahim Malang, Malang 65144, East Java, Indonesia. Corresponding author: Retno Susilowati, e-mail: retno.susilowati@bio.uin-malang.ac.id Co-author: AMS: abdul.malik.setiawan@kedokteran.uin-malang.ac.id

Received: 18-02-2020, Accepted: 29-05-2020, Published online: 22-07-2020

doi: www.doi.org/10.14202/vetworld.2020.1404-1409 How to cite this article: Susilowati R, Setiawan AM (2020) Cinnamomum burmannii (Nees \& T. Nees) Blume and Eleutherine palmifolia (L.) Merr. extract combination ameliorate lipid profile and heart oxidative stress in hyperlipidemic mice, Veterinary World, 13(7): 1404-1409.

\begin{abstract}
Background and Aim: Hyperlipidemia is an important risk factor for cardiovascular disease. The use of statins has adverse side effects that result in oxidative stress disorders. The objective of this study was to investigate the antihyperlipidemic effect of a combination of Cinnamomum burmannii and Eleutherine palmifolia extract in high-fat diet (HFD)-induced hyperlipidemia mice.

Materials and Methods: Mice were divided into eight groups ( $\mathrm{n}=4)$ : Control group or healthy mice (normal), HFDinduced hyperlipidemic mice without any treatment (CE0), HFD-induced hyperlipidemic mice treated with $3.6 \mathrm{mg} / \mathrm{kg}$ body weight (BW) atorvastatin (atorvastatin), and HFD-induced hyperlipidemic mice treated with a combination of $C$. burmannii and E. palmifolia in the following ratios: 300:0 (C300), 225:75 (C225), 150:150 (CE150), 75:225 (E225), and 0:300 (E300). Mice were fed a HFD for 4 months to induce hyperlipidemia. Total cholesterol, cholesterol oxidase-peroxidase aminophenazone (CHOD-PAP), triglyceride-glycerine, and fat serum were analyzed with colorimetric method. The measurement of superoxide dismutase was done with the xanthine oxidase method and malondialdehyde measurement was done with the thiobarbituric acid method.
\end{abstract}

Results: Results showed an increase in antihyperlipidemic characteristics as the concentration of E. palmifolia extract $(\mathrm{p}<0.05)$ increased. Duncan's multiple range test also showed an increase in anti-stress oxidation as the concentration of C. burmannii extract $(\mathrm{p}<0.05)$ increased.

Conclusion: The E225 group showed the most potential as a safe, antihyperlipidemic agent characterized by improvement in lipid profile and antioxidant balance.

Keywords: antihyperlipidemic, Cinnamomum burmannii, Eleutherine palmifolia, lipid profile, malondialdehyde, superoxide dismutase.

\section{Introduction}

Hyperlipidemia is a medical condition characterized by the elevation of any or all lipid profiles and/or lipoproteins in the blood and is also called hypercholesterolemia or hyperlipoproteinemia [1,2]. Although elevated low-density lipoprotein cholesterol (LDL-C) is thought to be the best indicator of atherosclerosis risk, hyperlipidemia can be determined by elevation of total cholesterol (TC) or triglyceride (TG) levels, or by low levels of high-density lipoprotein-C (HDL-C) [3]. Elevated LDL-C and TGs in hyperlipidemia correlate to cardiovascular disease (CVD), diabetes [4], and hypertension [5]. Moreover, ischemic

Copyright: Susilowati and Setiawan. Open Access. This article is distributed under the terms of the Creative Commons Attribution 4.0 International License (http://creativecommons.org/licenses/ by/4.0/), which permits unrestricted use, distribution, and reproduction in any medium, provided you give appropriate credit to the original author(s) and the source, provide a link to the Creative Commons license, and indicate if changes were made. The Creative Commons Public Domain Dedication waiver (http:// creativecommons.org/publicdomain/zero/1.0/) applies to the data made available in this article, unless otherwise stated. heart patients have increased oxidative stress levels characterized by an elevation in malondialdehyde (MDA) levels [6]. Therefore, hyperlipidemic therapy is needed to decrease cases of diabetes mellitus, CVD, and hypertension [4]. Statins are currently used for treatment of hyperlipidemia, but they cause side effects and myopathy. Side effects of statins commonly relate to skeletal muscles and include muscle cramping, soreness, weakness, and fatigue [7]. Safe hyperlipidemic treatment is needed as an alternative to long-term and costly statin treatment.

Phenol is an organic compound with antioxidant and lipid reduction potential [8,9]. Cinnamon (Cinnamomum burmannii [Nees \& T. Nees] Blume) is rich in phenols and flavonoids, including cinnamyl alcohol, coumarin, acid cinnamic, cinnamaldehyde, anthocyanin, and essential oils with a glucose constituent, protein, crude fat, pectin, etc. C. burmannii exhibits high biological activity, acting as an analgesic, antibacterial, antidiabetic, antifungal, antioxidant, antirheumatic, antithrombotic, and antitumor agent [10]. 
The addition of $15 \%$ cinnamon powder or $20 \mathrm{mg} /$ body weight (BW) to the daily diet for 35 days may reduce TC, TGs, and LDL significantly, but not as effective as a daily dose of atorvastatin $0.2 \mathrm{mg} / \mathrm{kg} \mathrm{BW}$ [11]. Cinnamaldehyde is the main compound in cinnamon bark [12-14]. Administration of $20 \mathrm{mg} / \mathrm{kg}$ cinnamaldehyde for 4 weeks reduced TG levels and increased HDL in spontaneous diabetic mice model of type 2 diabetes (C57blks/j db/db mice) [15]. Bawang dayak (Eleutherine palmifolia (L.) Merr) is a plant endemic to Borneo, Indonesia. E. palmifolia has been used empirically in therapy for several diseases, such as breast cancer, hypertension, diabetes, high cholesterol, ulcers, colorectal cancer, and strokes. E. palmifolia contains a high level of quercetin [14], which reduces the expression of the lipid, oleic acid, and sterol regulatory element-binding protein-1, and also inhibits the transcription of $\beta$-hydroxy $\beta$-methylglutaryl-coenzyme A (HMG-CoA), glycerol-3-phosphate acyltransferase, acetyl-CoA carboxylase, and fatty acid synthetase [16]. Long-term hyperlipidemia is characterized by oxidative stress imbalance and results in serious health disorders, such as atherosclerosis, stroke, and heart attack. The increase in MDA lipid peroxide inhibits the contractile function of the heart muscle which directly activates p38 mitogen-activated protein kinase and causes muscle cell length reduction and peak shortening [17]. At present, supporting scientific data are lacking for the use of this plant in hyperlipidemia prevention.

C. burmannii and E. palmifolia have different dominant active compounds and mechanisms against hyperlipidemia. C. burmannii bark is rich in cinnamaldehyde, whereas E. palmifolia is rich in quercetin. To maximize the antihyperlipidemic activity of both plants, we used a combination extract. Therefore, this study aimed to investigate the potential effect of C. burmannii and E. palmifolia combination extract on the regulation of lipid profiles and antioxidant activity by measuring MDA levels in the heart muscle tissue of high-fat diet (HFD)-induced hyperlipidemic mice.

\section{Materials and Methods}

\section{Ethical approval}

Animal maintenance and handling were in accordance with Principles of Laboratory Animal Care (NIH publication no. 85-23, revised 1985) [18]. The type of feed was standard chow diet and water ad libitum. Mice were obtained from Rattus Breeding Centre, Malang, Indonesia. All the protocols for animal study were approved by Ethics Commission of the Faculty of Science and Technology of UIN Maulana Malik Ibrahim Malang (no. 015/EC/KEP. FST/2018).

\section{Preparation of plant extract}

Bark of C. burmannii and bulbs of E. palmifolia were obtained from UPT Materia Medica, Lahore street No. 87, Pesanggrahan, Batu, East Java, Indonesia. The plants were dried at $60^{\circ} \mathrm{C}$, mashed, and filtered through an 80-mesh filter. A $500 \mathrm{~g}$ of plant powder was dissolved in $96 \%$ ethanol $(1: 3, \mathrm{w}: \mathrm{v})$ for
$72 \mathrm{~h}$. The filtrate was then evaporated with a rotary evaporator to obtain the concentrated extract.

\section{Study period and location}

This study was conducted from April 15, 2019 until October 31, 2019 in Animal Physiology Laboratorium, Plant Physiology Laboratorium and Animal Room, Department of Biology, Faculty of Science and Technology, State Islamic University of Maulana Malik Ibrahim Malang, Indonesia and Biomedical Laboratorium, Muhammadiyah University of Malang, Indonesia.

\section{Design of animal experiment}

Thirty-two female Balb/c mice of the same age ( 8 weeks) and weight ( $25 \mathrm{~g}$ ) were selected for this study. Mice were acclimated for 7 days at $25-27^{\circ} \mathrm{C}$ under 12 $\mathrm{h}$ light-dark cycles. Mice were fed a standard chow diet and provided ad libitum access to water. Balb/c mice were then divided into eight groups (four mice/group): Control normal diet mice (normal), HFD-induced hyperlipidemic mice without any treatment (CE0), HFD-induced hyperlipidemic mice treated with $3.6 \mathrm{mg} /$ $\mathrm{kg} \mathrm{BW}$ atorvastatin (atorvastatin), and HFD-induced hyperlipidemic mice treated with a $C$. burmannii and E. palmifolia combination extract in the following ratios, 300:0 (C300), 225:75 (C225), 150:150 (CE150), 75:225 (E225), and 0:300 (E300). Hyperlipidemia was induced by a HFD, cholesterol, and propylthiouracil (PTU) administration. For 120 days, mice of all HFD treatment groups had ad libitum access to HFD pellets containing quail egg yolk (10\%) and bovine fat $(10 \%)$. Seventeen and one-half $\mathrm{mg}$ of cholesterol in $0.3 \mathrm{ml}$ of oil was administered through oral gavage. Mice had ad libitum access to water containing $0.01 \%$ PTU [19].

\section{Serum and heart tissue isolation}

After 120 days of treatment with the experimental diet, animals were sacrificed. Blood and heart tissue were isolated immediately. Blood was collected from the ventricles of all mice after fasting for $8 \mathrm{~h}$. The blood samples were centrifuged at $1500 \mathrm{rpm}$ for $15 \mathrm{~min}$. Serum was collected and stored in $-20^{\circ} \mathrm{C}$ for further analysis. Heart tissue was isolated and washed with phosphate-buffered saline (PBS). A $0.1 \mathrm{~g}$ of heart organ was homogenized by adding $1 \mathrm{ml}$ PBS, $\mathrm{pH}$ 7.07.4. Then, the homogenate was centrifuged at 3000 $\mathrm{rpm}, 4^{\circ} \mathrm{C}$ for $15 \mathrm{~min}$. Lysate heart tissue was isolated and stored at $-20^{\circ} \mathrm{C}$ for further superoxide dismutase (SOD) and MDA measurement (manual procedure of catalog No. E-BC-K020-M, E-BC-K025-S).

\section{Lipid, SOD, and MDA measurement}

Levels of TC, TGs, and LDL in serum were measured using an enzymatic colorimetric method [20] with a reagent of TC assay kit (CHOD-phosphate oxidase peroxidase [PAP] method) and TG assay kit (single reagent, glycerine PAP method; Elabscience ${ }^{\circledR}$, China). Sample absorbance was measured with an EZ Read 400 Microplate Reader. SOD level was measured with the xanthine oxidase method [21] using 
an SOD activity assay kit (hydroxylamine method; Elabscience $^{\circledR}$ ). MDA was measured with the thiobarbituric acid method (Elabscience ${ }^{\circledR}$ ).

\section{Statistical analysis}

All of the experimental data were represented as mean \pm standard deviation. Analysis of variance and Duncan's multiple range test were performed using SPSS version 16.0 for Windows (SPSS, Inc., Chicago, IL, USA). $\mathrm{p}<0.05$ was considered statistically significant.

\section{Results}

\section{Lipid profile of mouse blood serum}

To evaluate the antihyperlipidemic effects of C. burmannii and E. palmifolia, we analyzed the changes in serum lipid profiles of HFD-induced hyperlipidemic mice. The results showed that all lipid profiles (TC, TGs, and LDL-C) were higher in the HFD-treated group than in the normal group (Table-1). The concentration of TC significantly $(p<0.05)$ decreased in hyperlipidemic mice treated with the single and a combination extract of $C$. burmannii and a combination of $C$. burmannii and E. palmifolia. The decrease in TC in the $\mathrm{C} 300$ and $\mathrm{C} 225$ groups was close to the atorvastatin group. The levels of TC in the CE150, E225, and E300 groups were not significantly different than the normal and atorvastatin groups ( $p>0.05$ ). Furthermore, the single extract of $C$. burmannii and in combination with E. palmifolia reduced TG and LDL-C significantly $(\mathrm{p}<0.05)$ compared to the hyperlipidemic group. The TGs of the C300 and C225 groups were close to the TGs of the atorvastatin group, while the levels of TGs and LDL-C in the E225 and E300 groups were not significantly different from normal $(\mathrm{p}>0.05)$.

\section{Oxidative stress in heart muscle of mice}

The level of oxidative stress was significantly increased in the HFD-treated group, which was characterized by an elevation in MDA levels and reduction in SOD activity. Interestingly, the single extract of $C$. burmannii and in combination with $E$. palmifolia significantly $(\mathrm{p}<0.05)$ reduced MDA levels compared to the hyperlipidemic group (CE0; Figure-1). All groups of combination extract (excluding E300) had significantly reduced MDA levels close to those of the atorvastatin group. Furthermore, the single and/or a combination extract of $C$. burmannii and E. palmifolia increased the activity of SOD significantly (excluding E300) compared to the hyperlipidemic group to normal level $(\mathrm{p}<0.05)$. The E300 group had a reduced MDA and increased SOD level close to that of the atorvastatin group ( $\mathrm{p}>0.05)$.

\section{Discussion}

The present study revealed that the combination of $150 \mathrm{mg} / \mathrm{kg} \mathrm{C}$. burmannii and $150 \mathrm{mg} / \mathrm{kg}$ E. palmifolia extract (CE150 group) and the combination of $75 \mathrm{mg} / \mathrm{kg}$ E. palmifolia and $225 \mathrm{mg} / \mathrm{kg}$ C. burmannii extract (E225 group) exhibited high reduction in lipid profile levels compared to the other treatment groups. This was supported by the antihyperlipidemic activity of each plant. Ethanolic extract of C. burmannii reduced lipid and lipoprotein profiles. Cinnamon consumption of $120 \mathrm{mg} /$ day to $6 \mathrm{~g}$ /day for 4-18 weeks reduced TC, TGs, and LDL [22,23]. Patients with metabolic syndrome that consumes cinnamon (six capsules or three g) daily or wheat flour showed better results than Febrinda et al. [24] who reported ethanolic and water extract of $C$. burmannii in $100 \mathrm{mg} / \mathrm{kg} \mathrm{BW}$ dose reduced TC and LDL in alloxan-induced diabetic mice $(110 \mathrm{mg} / \mathrm{kg} \mathrm{BW})$ for 4 days before treatment. However, there was no significant effect on HDL and TG levels. The administration of cinnamon water extraction at a dose of $100 \mathrm{mg} / \mathrm{kg}$ BW for 6 weeks significantly reduced cholesterol and TGs in HFD- and alloxan-induced rat serum which

Table-1: Serum lipid profile, MDA, and SOD activity of heart muscle of HFD-induced mice.

\begin{tabular}{|c|c|c|c|c|c|}
\hline \multirow[t]{2}{*}{ Treatment } & \multicolumn{5}{|c|}{ Variable } \\
\hline & $\mathrm{TC}(\mathrm{mg} / \mathrm{dl})$ & TG (mg/dl) & LDL (mg/dl) & SOD (U/ml) & MDA $(\mathrm{nmol} / \mathrm{ml})$ \\
\hline Normal & $153.32 \pm 15.80^{a}$ & $48.48 \pm 7.70^{a}$ & $138.80 \pm 13.28^{a}$ & $10.04 \pm 0.47^{b c}$ & $2.40 \pm 0.26^{b}$ \\
\hline Atorvastatin & $177.93 \pm 60.75^{\mathrm{ab}}$ & $90.08 \pm 4.71^{b}$ & $139.59 \pm 8.32^{\mathrm{a}}$ & $17.3 \pm 2.32^{f}$ & $2.40 \pm 0.29^{b}$ \\
\hline CEO & $326.95 \pm 61.83^{c}$ & $181.93 \pm 36.47^{e}$ & $227.08 \pm 35.19^{c}$ & $7.43 \pm 0.73^{a}$ & $3.17 \pm 0.25^{c}$ \\
\hline C300 & $243.75 \pm 28.46^{b}$ & $95.42 \pm 4.49^{b}$ & $255.21 \pm 43.57^{c}$ & $13.5 \pm 1.40^{\mathrm{e}}$ & $1.77 \pm 0.56^{\mathrm{ab}}$ \\
\hline C225 & $210.35 \pm 52.41^{b}$ & $83.21 \pm 5.54^{b}$ & $219.53 \pm 47.85^{\mathrm{bc}}$ & $12.76 \pm 0.80^{\mathrm{de}}$ & $2.03 \pm 0.24 \mathrm{ab}$ \\
\hline CE150 & $190.04 \pm 48.05^{\mathrm{ab}}$ & $132.83 \pm 18.82^{c}$ & $239.06 \pm 8.93^{c}$ & $10.56 \pm 1.16^{\mathrm{bc}}$ & $1.80 \pm 0.48 \mathrm{ab}$ \\
\hline E225 & $193.36 \pm 31.42^{\mathrm{ab}}$ & $53.95 \pm 6.31^{\mathrm{a}}$ & $170.31 \pm 20.85^{a}$ & $11.16 \pm 1.01^{\mathrm{cd}}$ & $1.96 \pm 0.70^{\mathrm{ab}}$ \\
\hline E300 & $219.34 \pm 55.99^{a b}$ & $45.29 \pm 4.84^{a}$ & $173.96 \pm 43.63^{\mathrm{ab}}$ & $8.71 \pm 1.50^{\mathrm{ab}}$ & $1.54 \pm 0.69^{a}$ \\
\hline Statistical test & $\begin{array}{l}\text { ANOVA } p<0.01 \\
\text { DMRT } a=0.05\end{array}$ & $\begin{array}{l}\text { ANOVA } p<0.01 \\
\text { DMRT } a=0.05\end{array}$ & $\begin{array}{l}\text { ANOVA } p<0.01 \\
\text { DMRT } a=0.05\end{array}$ & $\begin{array}{l}\text { ANOVA } p<0.01 \\
\text { DMRT } a=0.05\end{array}$ & $\begin{array}{l}\text { ANOVA } p<0.01 \\
\text { DMRT } a=0.05\end{array}$ \\
\hline \multicolumn{6}{|c|}{$\begin{array}{l}\text { Normal (healthy mice), atorvastatin ( } 3.6 \mathrm{mg} / \mathrm{kg} \mathrm{BW} \text { of atorvastatin), CEO (HFD-induced hyperlipidemia mice without } \\
\text { treatment), C300 (HFD-induced hyperlipidemia mice treated with } 300 \mathrm{mg} / \mathrm{kg} \mathrm{C.} \mathrm{burmannii),} \mathrm{C225} \mathrm{(HFD-induced} \\
\text { hyperlipidemia mice treated with } 225 \mathrm{mg} / \mathrm{kg} \mathrm{C.} \mathrm{burmannii}+75 \mathrm{mg} / \mathrm{kg} \text { E. palmifolia), CE150 (HFD-induced hyperlipidemia } \\
\text { mice treated with } 150 \mathrm{mg} / \mathrm{kg} \mathrm{C.} \mathrm{burmannii}+150 \mathrm{mg} / \mathrm{kg} \text { E. palmifolia), E225 (HFD-induced hyperlipidemia mice } \\
\text { treated with } 75 \mathrm{mg} / \mathrm{kg} \mathrm{C.} \mathrm{burmannii}+225 \mathrm{mg} / \mathrm{kg} \mathrm{E.} \mathrm{palmifolia),} \mathrm{and} \mathrm{E300} \mathrm{(HFD-induced} \mathrm{hyperlipidemia} \mathrm{mice} \mathrm{treated} \\
\text { with } 300 \mathrm{mg} / \mathrm{kg} \mathrm{E.} \mathrm{palmifolia).} \mathrm{TC=Total} \mathrm{cholesterol,} \mathrm{TG=Triglyceride,} \mathrm{LDL=Low-density} \mathrm{lipoprotein,} \mathrm{SOD=Superoxide} \\
\text { dismutase, MDA=Malondialdehyde. HFD=High-fat diet, BW=Body weight, E. palmifolia=Eleutherine palmifolia, } \\
\text { C. burmannii=Cinnamomum burmannii }\end{array}$} \\
\hline
\end{tabular}




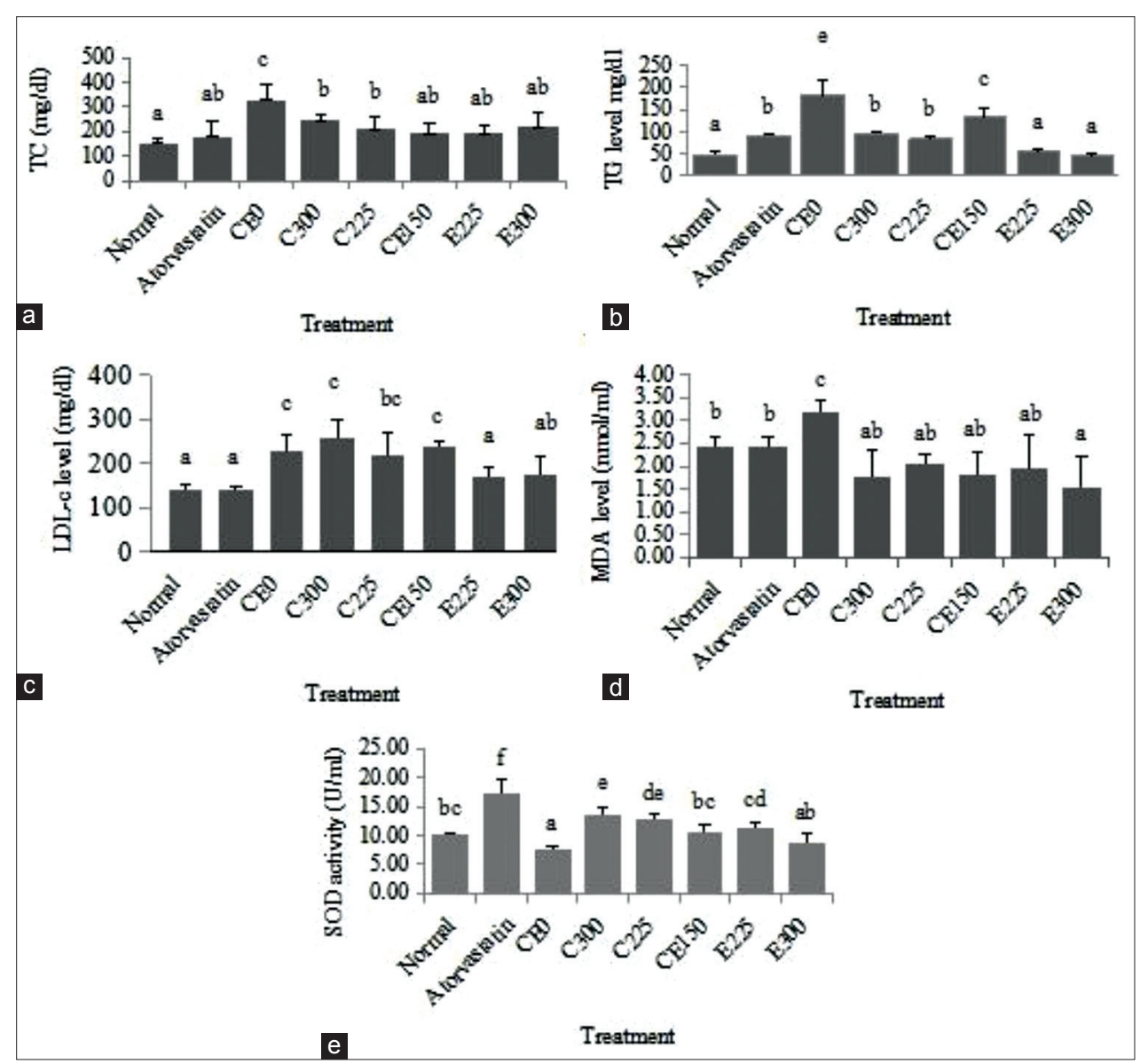

Figure-1: Lipid profile, malondialdehyde, and superoxide dismutase activity of heart muscle in high-fat diet-induced mice.

previously increased HDL-C and reduced LDL-C serum [25]. Water-alcoholic extract of cinnamon at a dose of $100 \mathrm{mg} / \mathrm{kg}$ BW for 12 weeks reduced TC and TG blood serum levels, but they did not reach a normal level and lowered HDL to the same level as in a normal diet [26].

C. burmannii extract can act as an antihyperlipidemic agent due to the high amount of cinnamaldehyde in the bark. The level of cinnamaldehyde in cinnamon bark is about $65-80 \%$, while in leaves is only $1-5 \%$. In addition, cinnamon also contains eugenol, which is about $5-10 \%$ in the bark and about $70-95 \%$ in the leaves [27]. This hypothesis is supported by previous research which found that the addition of $2 \%$ cinnamaldehyde to the diet for 5 weeks significantly reduced the BW of obesity-induced mice. This finding also showed a reduction of TC and TGs resulting from cinnamaldehyde compound [28].

The antihyperlipidemic effects of combination extract are supported by the role of single plant extract of E. palmifolia, which has several active compounds in the bulb. The main bioactive compounds of the ethanolic extract of E. palmifolia are gallic acid $(97.37 \mathrm{mg})$, epicatechin gallate $(80.17 \mathrm{mg})$, quercetin $(64.8 \mathrm{mg})$, Eleutherine $(33.42 \mathrm{mg})$, and rutin (29.94 mg) [29]. This study showed better results than the previous one, which reported that $2 \%$ methanolic extraction of E. palmifolia for 1 week did not reduce
TC and TGs in blood serum [30]. Daily administration of gallic acid protected against hepatic steatosis, obesity, hypercholesterolemia, and insulin resistance among HFD-induced nonalcoholic fatty liver disease mice [31]. Ethanol extract of E. palmifolia at a dose of $100-400 \mathrm{mg} / \mathrm{kg} \mathrm{BW}$ for 14 days did not reduce the MDA level in an alloxan-induced diabetic rat [32]. This study demonstrated that combination extract could significantly increase SOD activity in heart muscle of hyperlipidemic mice. This finding was in line with other research which proved that ethanolic extract of Cinnamomum zeylanicum and Cinnamomum cassia at a dose of $600 \mathrm{mg} / \mathrm{kg} \mathrm{BW}$ significantly increased the levels of SOD, glutathione peroxidase (GPx), and GSH in the liver of streptozotocin-induced rat [33]. The result is also supported by Yuanita et al. [30], who found that methanol extract of E. palmifolia significantly increased SOD and reduced MDA in chicken blood. The highest antioxidant activity of E. palmifolia was found through a DPPH test of extract obtained by $50 \%$ methanol [34], and a dose of $100-200 \mathrm{mg} / \mathrm{kg}$ BW increased the activity of SOD, GPx, and catalase but not to normal levels [25].

This study showed that the E225 group exhibited the best results for improving all parameters. This is in accordance with Prakash et al. [35], who proved that the four extracts together were more effective than a single extract or combination of two extracts 
against free radicals. Even though the components of the extract are the same, different amounts of each extract produce different results in reducing the levels of lipids, lipoproteins, and oxidative stress [36]. This might be caused by several different pathways for each parameter and different active compounds in the extract, resulting in different synergistic mechanisms.

Several studies have supported the antihyperlipidemic mechanisms of combination extract. Quercetin from $C$. burmannii can inhibit cholesterol synthesis by inhibiting the activity of HMG-CoA reductase [37]. Moreover, tannic acid and gallic acid have a high affinity for cholesterol [38]. In addition, the inhibitory effects on digestion and absorption of cholesterol in the gastrointestinal tract were induced by catechin, epicatechin, and epicatechin gallate from $E$. palmifolia [39]. The inhibition of lipids and cholesterol absorption during food digestion is very effective in ameliorating the increase of lipids and cholesterol through external channels, thereby reducing its accumulation in the body. Thus, E. palmifolia has more potential as an antihyperlipidemic than $C$. burmannii. Aside from being involved in $\mathrm{HMG}-\mathrm{CoA}$ reductase inhibition, quercetin and kaempferol from $C$. burmannii also act as powerful natural antioxidants [40]. Hydrogen donation is the main mechanism of phenolics as antioxidants. The lower strength of the $\mathrm{O}-\mathrm{H}$ bond present in phenolics corresponds to a higher scavenging activity. Quercetin and kaempferol identified in Cinnamomum species have a C2-C3 double bond and a C-3 hydroxyl group, while the most active hydroxyl groups are those attached to the $\mathrm{C} 4$ and $\mathrm{C} 3$ positions [41]. This research found that a daily dose composed of $225 \mathrm{mg} / \mathrm{kg}$ E. palmifolia and $75 \mathrm{mg} / \mathrm{kg}$ C. burmannii showed the most potential effect as an antihyperlipidemic agent.

\section{Conclusion}

The combination of C. burmannii and E. palmifolia extract has more potential effect as a safe antihyperlipidemic agent, compared to single plant extracts, in improving blood lipid, and lipoprotein profiles and also preventing oxidative stress in the hearts of hyperlipidemic mice. The combination E225 extract (225 mg/kg E. palmifolia and $75 \mathrm{mg} / \mathrm{kg}$ C. burmannii) is a safe antihyperlipidemic agent due to its neutralization of oxidative stress, and normalization of lipid and lipoprotein levels, in hyperlipidemic mice.

\section{Authors' Contributions}

RS contributed to conceptual design, conducted the experiment and wrote the manuscript. AMS performed data analysis and revised the manuscript. Both authors read and approved the final manuscript.

\section{Acknowledgments}

This study was supported by DIPA, State Islamic University of Maulana Malik Ibrahim Malang, Indonesia, with grant no. 482 (2019).

\section{Competing Interests}

The authors declare that they have no competing interests.

\section{Publisher's Note}

Veterinary World remains neutral with regard to jurisdictional claims in published institutional affiliation.

\section{References}

1. Harikumar, K., Althaf, S.A., Kishore, B., Ramunaik, M. and Suvarna, C.H. (2013) A review on hyperlipidemic. Int. J. Nov. Trends Pharm. Sci., 3(4): 59-70.

2. Shattat, G.F. (2014) A review article on hyperlipidemia: Types, treatments and new drug targets. Biomed. Pharmacol. J., 7(2): 399-409.

3. Onwe, P., Folawiyo, M., Anyigor, C., Umahi, G. and Okorocha, A. (2015) Hyperlipidemia: etiology and possible control. IOSR J. Dent. Med Sci., 14(10): 93-100.

4. Warraich, H.J. and Rana, J.S. (2017) Dyslipidemia in diabetes mellitus and cardiovascular disease. Cardiovasc. Endocrinol. Metab., 6(1): 27-32.

5. Ariyanti, R. and Besral, B. (2019) Dyslipidemia associated with hypertension increases the risks for coronary heart disease: A case-control study in Harapan Kita hospital, national cardiovascular center, Jakarta. Diet. Lipids Health Dis., 2019: Article ID 2517013.

6. Sarkar, P.D. and Rautaray, S.S. (2009) A study of serum malondialdehyde levels and paraoxanase activity in ischemic stroke patients. Biomed. Res., 20(1): 64-66.

7. Di Stasi, S.L., MacLeod, T.D., Winters, J.D. and BinderMacleod, S.A. (2010) Effects of statins on skeletal muscle: A perspective for physical therapists. Phys. Ther., 90(10): 1530-1542.

8. Afonso, M.S., de O Silva, A.M., Carvalho, E.B., Rivelli, D.P., Barros, S.B., Rogero, M.M., Lottenberg, A.M., Torres, R.P. and Mancini-Filho, J. (2013) Phenolic compounds from Rosemary (Rosmarinus officinalis L.) attenuate oxidative stress and reduce blood cholesterol concentrations in diet-induced hypercholesterolemic rats. Nutr. Metab. (Lond), 10(1): 19.

9. Zeni, A.L.B., Moreira, T.D., Dalmagro, A.P., Camargo, A., Bini, L.A., Simionatto, E.L. and Scharf, D.R. (2017) Evaluation of phenolic compounds and lipid-lowering effect of Morus nigra leaves extract. An. Acd. Bras. Cienc., 89(4): 2805-2815.

10. Al-Dhubiab, B.E. (2012) Pharmaceutical applications and phytochemical profile of Cinnamomum burmannii. Pharmacogn. Rev., 6(12): 125-131.

11. Rahman, S., Begum, H., Rahman, Z., Ara, F., Iqbal, M.J. and Yousuf, A.K.M. (2013) Effect of cinnamon (Cinnamomum cassia) as a lipid lowering agent on hypercholesterolemic rats. J. Enam Med. Coll., 3(2): 94-98.

12. He, Z., Qiao, C., Han, Q., Cheng, C., Xu, H., Jiang, R., But, P.P. and Shaw, P. (2005) Authentication and quantitative analysis on the chemical profile of cassia bark (Cortex cinnamomi) by high-pressure liquid chromatography. J. Agric. Food Chem., 53(7): 2424-2428.

13. Barceloux, D.G. (2012) Medical Toxicology of Natural Substances: Foods, Fungi, Medicinal Herbs, Plants, and Venomous Animals. John Wiley and Sons, New York.

14. Martín, J., Navas, M.J., Jiménez-Moreno, A.M. and Asuero, A.G. (2017) Phenolic Compounds Natural Sources, Importance and Applications, Anthocyanin Pigments: Importance, Sample Preparation and Extraction. The University of Seville, Seville, Spain.

15. Li, J., Liu, T., Wang, L., Guo, X., Xu, T., Wu, L., Qin, L. and Sun, W. (2012) Antihyperglycemic and antihyperlipidemic action of cinnamaldehyde in C57blks/j Db/db mice. 
J. Tradit. Chin. Med., 32(3): 446-452.

16. Wu, C.H., Lin, M., Wang, H., Yang, M., Jou, M. and Wang, C. (2011) Rutin inhibits oleic acid induced lipid accumulation via reducing lipogenesis and oxidative stress in hepatocarcinoma cells. J. Food Sci., 76(2): 65-72.

17. Folden, D.V., Gupta, A., Sharma, A.C., Li, S. and Saari, J.T. (2003) Malondialdehyde inhibits cardiac contractile function in ventricular myocytes via a p38 mitogen-activated protein kinase-dependent mechanism. Br. J. Pharmacol., 139(7): 1310-1316.

18. Derrell, C. (1996) Guide for the Care and Use of Laboratory Animals. Institute of Laboratory Animal Resources, Washington DC, USA.

19. Amirabadizadeh, A., Foaddodini, M., Khatamsaz, S., Moktari, M., Shariati, M., Hosseini, M. and Hajipoor, F. (2017) Introduction and optimization of a dietary model for inducing hyperlipidemia in rats. J. Babol. Univ. Med. Sci., 19(7): 35-41.

20. Chin, Y.K. (2006) Comparative sensitivities of cholesterol analysis using GC, HPLC and spectrophotometric methods. Malays. J. Anal. Aci., 10(2): 205-210.

21. Kuyumcu, F. and Aycan, A. (2018) Evaluation of oxidative stress levels and antioxidant enzyme activities in burst fractures. Med. Sci. Monit., 24: 225-234.

22. Allen, R.W. and Coleman, C.I. (2013) Cinnamon use in Type 2 diabetes: An updated systematic review and meta-analysis. Ann. Fam. Med., 11(5): 452-459.

23. Gupta, E., Purwar, S., Sundaram, S. and Rai, G.K. (2013) Nutritional and therapeutic values of Stevia rebaudiana: A review. J. Med. Plant Res., 7(46): 3343-3353.

24. Febrinda, A., Yuliana, N., Ridwan, E., Wresdiyanti, T. and Astawan, M. (2014) Hyperglycemic control and diabetes complication preventive activities of Bawang Dayak (Eleutherine palmifolia L. Merr.) Bulbs extracts in alloxan-diabetic rats. Int. Food Res. J., 21(4): 1405-1411.

25. Ismail, N.S. (2014) Protective effects of aqueous extracts of cinnamon and ginger herbs against obesity and diabetes in obese diabetic rat. World J. Dairy Food Sci., 9(2): 145-153.

26. Tuzcu, Z., Orhan, C., Sahin, N., Juturu, V. and Sahin, K. (2017) Cinnamon polyphenol extract inhibits hyperlipidemia and inflammation by modulation of transcription factors in high-fat diet-fed rats. Oxid. Med. Cell Longev., 2017: Article ID 1583098.

27. Rao, P.V. and Gan, S.H. (2014) Cinnamon: A multifaceted medicinal plant. Evid. Based Complement. Alternat. Med., 2014: Article ID 642942.

28. Camacho, S., Michlig, S., Senarclens-Bezençon, C. and Meylan, J. (2015) Effects of cinnamaldehyde via altered ghrelin secretion and functional impact. Sci. Rep., 5(7919): $1-10$.

29. Kamarudin, A.A., Mohd, N., Saad, N., Hafiza, N., Asma, N. and Razak, A. (2020) Industrial crops and products heat assisted extraction of phenolic compounds from Eleutherine bulbosa (Mill.) Bulb and its bioactive profiles using response surface methodology. Ind. Crop. Prod., 144: Article ID 112064

30. Yuanita, I., Sunarti, D., Wahyuni, H.I. and Suthama, N. (2019) Feeding dayak onion (Eleutherine palmifolia) extract and Lactobacillus acidophilus mixture on blood biochemicals, meat quality characteristics and growth performance in broiler chickens. Livest. Res. Rural Dev., 31(9): 144-149.

31. Chao, J., Huo, T., Cheng, H., Tsai, J., Liao, J., Lee, M. and Peng, W. (2014). Gallic acid ameliorated impaired glucose and lipid homeostasis in high fat diet-induced NAFLD mice. PLoS One., 9(6): e96969.

32. Damayanti, R. and Ma'ruf, A. (2017) The Effect of Dayak Onion (Eleutherine palmifolia) Tuber Extract in Liver Malondialdehyde (MDA) Level in Male Wistar Rats Induced by Alloxan. Proceedings of the $1^{\text {st }}$ International Conference Postgraduate School Universitas Airlangga. p330-332.

33. Prasanna, B. and Anand, A.V. (2019) Cinnamon species: In vivo antioxidant activity of ethanolic extracts of Cinnamon zeylanicum and Cinnamon cassicae Barks. Pharmacogn. J., 11(2): 245-247.

34. Agustin, A., Faika, S. and Ju, Y. (2016) Influence of extracting solvents on its antioxidant. Austr. J. Grape Wine Res., 6(2): 1-10.

35. Prakash, O., Singh, G.N., Singh, R.M., Madan, S. and Mathur, S.C. (2009) Interactions of herbal extract combinations against free radical scavenging activity. Pharm. Biol., 47(8): 729-733.

36. Visavadiya, N.P. and Narasimhacharya, A.V.R. (2011) Ameliorative effects of herbal combinations in hyperlipidemia. Oxid. Med. Cell. Longev., 2011: Article ID 160408 .

37. Jensi, V.D. and Gopu, P.A. (2018) Comparative analysis of quercetin and leucocynidin against HMG-CoA reductase and their evaluation of hypolipidemic activity. J. Pharm. Sci. Res., 10(12): 3417-3421.

38. Zeng, X., Sheng, Z., Li, X. and Jiang, W. (2019) In vitro studies on the interactions of blood lipid level-related biological molecules with gallic acid and tannic acid. J. Sci. Food Agric., 99(15): 6882-6892.

39. Kobayashi, M., Nishizawa, M., Inoue, N., Hosoya, T. and Yoshida, M. (2014) Epigallocatechin gallate decreases the micellar solubility of cholesterol via specific interaction with phosphatidylcholine. J. Agric. Food Chem., 62(13): 2881-2890.

40. Prasad, K.N., Yang, B., Dong, X., Jiang, G., Zhang, H., Xie, H. and Jiang, Y. (2009) Flavonoid contents and antioxidant activities from Cinnamomum species. Innov. Food Sci. Emerg. Technol., 10(4): 627-632.

41. Yang, J., Liu, B., Liang, G. and Ning, Z. (2009) Structureactivity relationship of flavonoids active against lard oil oxidation based on quantum chemical analysis. Molecules, 14(1): 46-52. 